\title{
Handbook of Florida Water Regulation: Hazardous Waste Management ${ }^{1}$
}

\author{
Michael T. Olexa, Luke D'Isernia, Laura Minton, Dulcy Miller, and Sarah Corbett ${ }^{2}$
}

\section{Preface}

This handbook is designed to provide an accurate, current, and authoritative summary of the principle Federal and Florida laws that directly or indirectly relate to agriculture. This handbook should provide a basic overview of the many rights and responsibilities that farmers and farmland owners have under both Federal and Florida laws as well as the appropriate contact information to obtain more detailed information. However, the reader should be aware that because the laws, administrative rulings, and court decisions on which this handbook is based are subject to constant revision, portions of this publication could become outdated at anytime. Several details of cited laws are also left out due to space limitations.

This handbook is distributed with the understanding that the authors are not engaged in rendering legal or other professional advice, and the information contained herein should not be regarded as a substitute for professional advice. This handbook is not all inclusive in providing information to achieve compliance with the Federal and Florida laws and regulations governing water protection. For these reasons, the use of these materials by any person constitutes an agreement to hold harmless the authors, the Florida Cooperative Extension Service, the Institute of Food and Agricultural Sciences, and the University of Florida for any liability claims, damages, or expenses that may be incurred by any person as a result of reference to or reliance on the information contained in this handbook.

\section{Who Regulates Hazardous Waste?}

The Resource Conservation and Recovery Act (RCRA) expressly states that the Environmental Protection Agency (EPA) need no longer enforce its rules within states that have passed their own, EPA-approved hazardous waste management programs. The EPA will approve those state programs that are at least as strict as the EPA regulations. Both the state and federal authorities have power to enforce essentially the same rules, although the Department of Environmental Protection (DEP) has made a few important additions that will be noted.

1. This is EDIS document FE612, a publication of the Food and Resource Economics Department, Florida Cooperative Extension Service, Institute of Food and Agricultural Sciences, University of Florida, Gainesville, FL. Published December 2005. Please visit the EDIS website at http://edis.ifas.ufl.edu.

2. Michael T. Olexa, Professor, Food and Resource Economics Department, Florida Cooperative Extension Service, Institute of Food and Agricultural Sciences, University of Florida, Gainesville, FL; Director, Agricultural Law Center, University of Florida, Gainesville, FL; and Chair, Agricultural Law Committee of The Florida Bar. Luke D'Isernia, former student (graduated cum laude in 2005), Levin College of Law, University of Florida, Gainesville, FL. Laura Minton, Attorney, Dean, Mead, Egerton, Bloodworth, Capouano, and Bozarth, Orlando, FL. Dulcy Miller, attorney, Foley and Lardner, LLP, Orlando, FL. Sarah Corbett, Attorney, Florida Second District Court of Appeal, Lakeland, FL.

The Institute of Food and Agricultural Sciences (IFAS) is an Equal Opportunity Institution authorized to provide research, educational information and other services only to individuals and institutions that function with non-discrimination with respect to race, creed, color, religion, age, disability, sex, sexual orientation, marital status, national origin, political opinions or affiliations. U.S. Department of Agriculture, Cooperative Extension Service, University of Florida, IFAS, Florida A. \& M. University Cooperative Extension Program, and Boards of County Commissioners Cooperating. Larry Arrington, Dean 
Hazardous waste management also falls into the realm of EPA regulation through two other acts: the federal Clean Water Act which prohibits all discharges of hazardous materials into navigable waters (FEFE82), and the Comprehensive Environmental Response, Compensation, and Liability Act (CERCLA) which provides a comprehensive approach to financing and executing hazardous waste spill cleanups (FE584).

\section{What Is Hazardous Waste?}

The EPA has compiled a lengthy list of specific chemicals and materials that are hazardous, and has also designated materials with certain characteristics as hazardous. Broadly stated, a hazardous waste is anything that can result in a serious threat to public health or the environment if mismanaged. More particularly, the EPA will look to each material's characteristics (e.g., toxicity, flammability, combustibility, corrosiveness and reactiveness).

Certain materials have been specifically designated as not hazardous, including:

- Household waste, (e.g, garbage, trash, and septic tank wastes).

- Solid wastes that are generated by the growing or harvesting of agricultural crops or by the raising of animals (including manure) and are returned to the soil as fertilizer.

- Slight residues in otherwise empty containers are generally not subject to regulation as hazardous waste (40 Code of Federal Regulations, Section 261.7).

\section{Who Is Responsible for Managing Hazardous Waste?}

The parties responsible for managing hazardous waste are the same five categories of potentially liable parties that are liable for cleanup costs under CERCLA:

1. Generators of hazardous substances (including small quantity generators)

2. Transporters of hazardous substances
3. Owners of treatment, storage, and disposal facilities

4. Operators of treatment, storage, and disposal facilities

\section{Arrangers (those who arrange for transporting} hazardous substances)

To ensure compliance with all statutes and rules, it is essential to determine if an individual fits into one or more of the five categories.

\section{Generators}

A generator is anyone who produces a hazardous waste. The EPA requires that all generators must obtain an identification number before they can treat, store, dispose, or transport their waste. Furthermore, the EPA sets standards for pre-transportation packaging and labeling of waste, and provides for an elaborate manifest record keeping system that allows the government to account for the waste from the point of its creation to its final disposal.

Generators may accumulate no more than 55 gallons of hazardous waste and one quart of "acutely" hazardous waste on-site for up to 90 days without a permit. After that, unless the EPA grants a 30-day extension for unforeseen delays in removing the waste, an owner/operator permit is required. Generators must follow all applicable laws dealing with storage and labeling of hazardous waste, and must take all required steps to prevent a spill of the hazardous waste and contamination.

Generators of more than 100 kilograms, but less than 1,000 kilograms of hazardous waste in a calendar month, may accumulate hazardous waste on-site for 180 days or less without a permit. However, the generator must comply with numerous requirements set forth by the EPA. For example, the quantity of waste on-site must never exceed 6,000 kilograms.

In addition to the EPA requirements, Florida law requires any generator who produces more than 1,000 pounds of hazardous waste in a year to file a separate report with the DEP at the end of that year. Federal law allows for certain exemptions to the permitting 
requirements. The two most important are small quantity generators and farm pesticide exemptions.

\section{Small Quantity Generators: Generators who} produce more than 100 kilograms, but less than 1,000 kilograms of hazardous waste in a calendar month, may be entitled to status as "small quantity generators" (SQG). SQGs are entitled under the federal rules to "conditional exemptions" such as exemptions from certain land-disposal restrictions, the right to accumulate waste on-site for longer periods of time without a permit, and greater disposal options. Under Florida law, all SQGs should be notified by the DEP, via the U.S. postal mail service, of their legal responsibilities and disposal alternatives. In response, each SQG is required, within 30 days of receiving the notification, to disclose to the DEP all waste management practices, including the types and quantities of waste handled. Failure to disclose this information can lead to fines of up to $\$ 100$ per day, for not more than 100 days.

2. Farm Pesticide Exemptions: Specifically exempt from the requirements governing generators are farmers who dispose of their own pesticides. They must, however, comply with the disposal instructions on the pesticide label and must triple-rinse each container.

\section{Transporters}

Like generators, transporters must obtain an identification number from the EPA and maintain detailed records of all wastes they handle. Transporters are not required to obtain an owner/operator permit so long as they do not store waste more than 10 days.

In the event of a spill, transporters must take all necessary action, including notification of crisis management authorities, in order to protect public health and the environment and to clean up the spill. Florida rules impose financial responsibility on transporters of at least $\$ 1$ million per accident, and require that all transporters submit evidence of adequate insurance coverage.

Transporters should note that they may also be subject to regulation by the U.S. Secretary of
Transportation under the Hazardous Materials Transportation Act (HMTA). The HMTA governs vehicular activities such as driving, parking, and refueling vehicles that are hauling, in commerce, any poisonous, flammable, combustible, corrosive, or other materials "which may pose an unreasonable risk to health and safety or property."

\section{Owner/Operators of Treatment, Storage, and Disposal Facilities}

Anyone involved in the treatment, storage, or disposal of hazardous waste must have a permit from the DEP and the EPA. The only relevant exceptions to this rule are the limited on-site accumulations allowed to generators, farm pesticide exceptions, and facilities that completely re-use waste in some other production process. The EPA has established extensive, detailed rules providing for the operation and security of such facilities. EPA also addresses personnel, safety, closure, and virtually every other aspect of maintaining a treatment, storage, or disposal facility.

On the state level, the DEP requires owner/operators to monitor and maintain the groundwater standards of their land and to report any changes to the DEP. Owner/operators, like transporters under Florida law, must be bonded and insured against accidents. No waste may be treated, stored, or disposed of anywhere except at a licensed facility. Waste may never be dumped into a sewage system or septic tank. Florida is working to discontinue the disposal of hazardous wastes through landfills.

The Florida Statutes authorize and subsidize local governments to set up local hazardous waste collection centers and instruct the DEP to set up "toxic roundups" in community centers where generators can deliver small amounts of hazardous waste (less than 100 pounds).

\section{Arrangers}

Arrangers are defined broadly as anyone involved in arranging for the transportation of hazardous waste, such as a middle man that contacted the transporter to ship the hazardous waste, etc. This is a catch-all category which assigns liability to 
parties that may not fit under the previous categories

yet were involved in the process of getting the hazardous waste transported.

\section{What Are the Penalties}

Both civil and criminal penalties, including prison, are available under the Clean Water Act (FE582), the Resource Conservation and Recovery Act (FE583), and the Comprehensive Environmental Response, Compensation, and Liability Act (FE584). The least severe penalties accompany negligent violations, while knowing violations and intentional violations each carry significantly greater penalties.

\section{Source}

42 United States Code, Sections 6901 to 6987 and 9601 to $9687 ; 33$ United States Code, Sections 1251 to 1387 ; 40 Code of Federal Regulations, Sections 260 to 272; Chapter 403, Florida Statutes, Sections 403.702 to 403.7893; Title 62, Florida

Administrative Code

\section{Contact Information}

Hazardous Waste Management (FE616, Contact Agencies)

- L-2, Hazardous Waste Compliance Section

- L-5, Clean Water Act FAcilities and Performance

- F-3, Emergency Planning and Community Right-to-Know

- F-4, TSCA Assistance Information Service

- F-6, Florida Administrator of EPA Pesticide Registration

\section{Acknowledgments}

The authors are indebted to the personnel of both state and federal agencies who provided their time and advice in the preparation of this handbook. The authors are especially indebted to Richard Budell of the Office of Agricultural Water Policy of the Florida Department of Agriculture and Consumer Services for providing funds for the development of this publication. 